\title{
MAMMALS OF THE HANFORD RESERVATION IN RELATION TO MANAGEMENT OF RADIOACTIVE WASTE
}

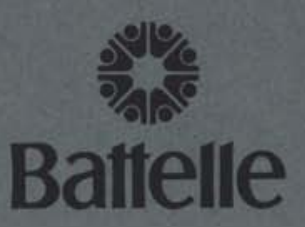

Pacific Northwest Laboratories

Richland, Washington 99352

\section{AUGUST 1974}

. Prepared for the U.S. Atomic Energy

Commission under Contract AT(45-1):1830 
NOTICE

The report was prepared as an account of work sponsored by the United States Government. Neither the United States nor the United States Atomic Energy Commission, nor any of their employees. nor any of their contractors, subcontractors, or their employees, makes any warranty, express or implied, or assumes any legal liability or responsibility for the accuracy, completeness or usefulness of any information, apparatus, product or process disclosed, or represents that its use would not infringe privately owned rights.

PACIFIC NORTHWEST LABORATORY operated by

BATTELLE for the

USS. ATOMIC ENERGY COMMISSION

Under Contract AT(45-1)-1830

" hinted in the United States of America Available from

National Technical Information Service.

U.S: Department of Commerce

528.5 Port Royal Road.

Springfield, Virginia 22151

, Price: Printed Copy 5.45; Microfiche 51.45 
BMM-1877

Special Distribution in

Cateaorv UC-70

MAMMALS OF THE HANFORD RESERVATION IN RELATION

TO MANAGEMENT OF RADIOACTIVE WASTE

W. H. Rickard, J. D. Hedlund and R. G. Schreckhise

Ecosystems Department

August 1974

This report was sponsored

by

The Atlantic Richfield Hanford Company under United States Atomic Energy Commission

Contract AT(45-1)-2130

BATTELLE,

PACIFIC NORTHMEST LABORATORIES

RICHLAND, WASHINGTON 99352 


\section{TABLE OF CONTENTS}

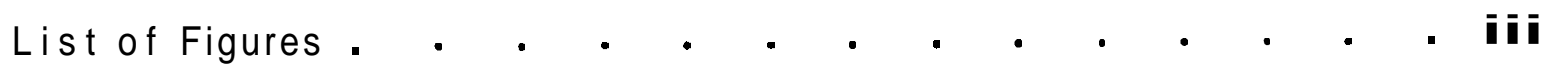
List of Tables. . . . . . . . . . . . . . .

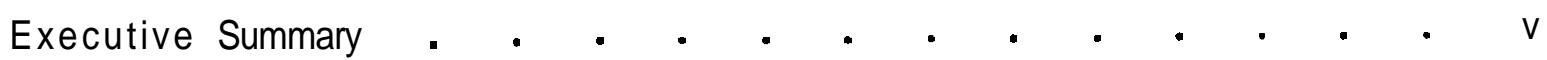
Introduction . . . . . . . . . . . . . . 1

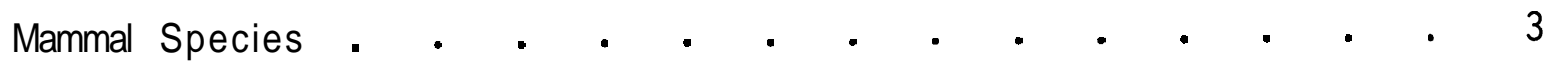
Herbivorous Mammals . • • • . • . • • . • . . 7 Mule Deer . • • • • • • • • • • • . • 7

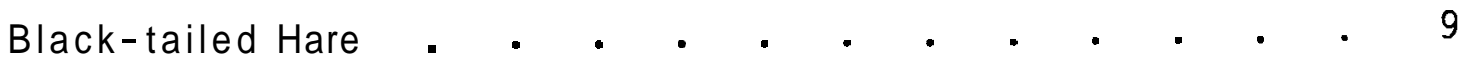
Cottontail Rabbit . . . . . . . . . . . . . . 11 Beaver . . . . . . . . . . . . . . . 12 Muskrat . . . . . . . . . . . . . . . 13

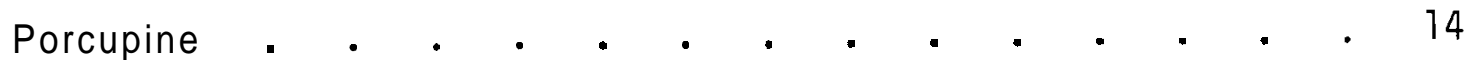
Great Basin Pocket Mouse . . . . . . . . . . 14 Townsend Ground Squirrel . . . . . . . . . . 16 Montane Meadow Mouse . . . . . . . . . . 16

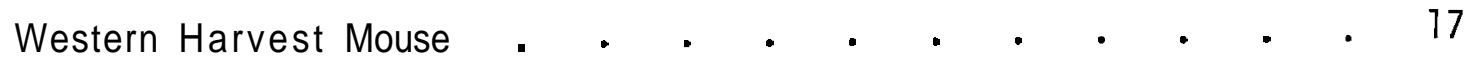
House Mouse . . . . . . . . . . . . . . 18 Northern Pocket Gopher . . . . . . . . 18 Sagebrush Vole. . • . • . . . . . • . . 19

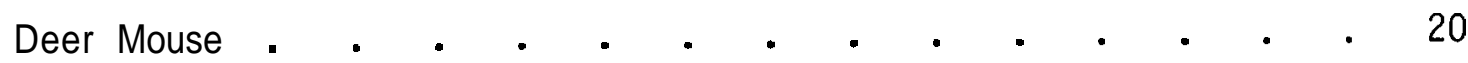

Bushy-tailed Wood Rat . . . . . . . • . . . 21 Norway Rat . • • • . • • • • • • • • . 21

Carnivorous Mammals . . . . . . . . . . . 22

Coyote . . . . . . . . . . . . . . 22

Badger . . . . . . . . . . . . . . 23

Bobcat . . . . . . . . . . . . 24

Raccoon . . • . . . • . • . • • . . 25

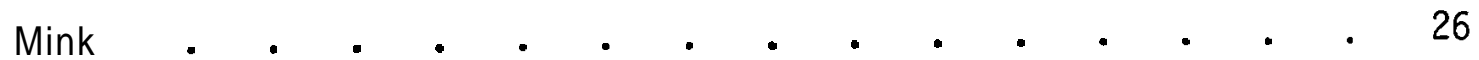

Striped Skunk . . . . . . . . . . • . . 27

Grasshopper Mouse . • • . . . . • • • • . 28

Vagrant Shrew . . . . . . . • . • • • . 28

Long-tailed Weasel . . . . . . . . . . . 29 
Mamma7s Occasionally Observed on the Hanford Reservation . . 31 Impact of Mammals on Plant Communities . . . . . . . . 33 Fences as Barriers to Mammals. . . . . . . . . . 35

Pocket Mice and Ground Squirrels . . . . . . . . 35

Coyotes and Badgers . . . . . . . . . . . 35

Muskrat and Raccoon . . . . . . . . . . . 35

Mule Deer . . . . . . . . . . . . . . 36

Black-tailed Hare . . . . . . . . . . . . 36

Radioecological Considerations. . . . . . . . . . 37

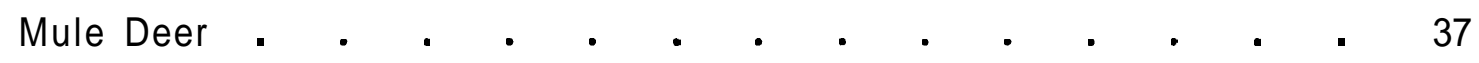

Mammals Other Than Deer . . . . . . . . . . 39

Radiation Effects. . . . . . . . . . . . 40

Basis For Future Work . . . . . . . . . . . . 43

References. . . . . . . . . . . . . . 45

Distribution . . . . . . . . . . . . . 49 


\section{LIST OF FIGURES}

1 Ecological distribution of mule deer on the Hanford

Reservation

\section{LIST OF TABLES}

1 Mammals of the Hanford Reservation . . . . . . . . 4

2 Mammals grouped according to habitat-type, food habits and size classes . . . . . . . . 5

3 Biological half-times of ${ }^{13^{\prime}} \mathrm{Cs}$ in various small mammals native to the Hanford Reservation. Modified from Winsor and O'Farrell (1970).

4 Response of Hanford mammals to acute radiation. Modified from O'Farrell and Hedlund (1970)

5 Mammals which warrant special consideration for the management of radioactive wastes. 


\section{EXECUTIVE SUMMARY}

Twenty-four species of mammals exclusive of bats are known to occur in or near waste management areas. Eight of these are important to waste management because of habitat requirements, food habits, burrowing behavior, potential for long-distance dispersal or positions in ecological food chains. These mammals are muskrat, raccoon, mule deer, coyote, badger, Townsend ground squirrel, black-tailed hare, and the Great Basin pocket mouse. Data concerning population density and home range are available only for the Great Basin pocket mouse. The role of fences as potential barriers to mammal dispersion and migration is discussed. A brief account is given of radionuclide behavior and of the response of mammals to acute ionizing radiation. 
MAMMALS OF THE HANFORD RESERVATION IN RELATION

TO MANAGEMENT OF RADIOACTIVE WASTE

\section{INTRODUCTION}

The Hanford Reservation consists of approximately 600 square miles of undeveloped semi-arid land located in Benton and Franklin Counties, southcentral Washington. The prominent topographic features are the Rattlesnake Hills attaining elevations to 3600 feet above mean sea level and forming the western boundary. The Saddle Mountains rise in elevation to 3000 feet to the north. The Rattlesnake Hills and Saddle Mountains are separated by the Columbia River and an expanse of monotonous topography interrupted only by a series of steep-walled cliffs along the north and east shores of the Columbia, locally known as "White Bluffs." An alignment of basaltic ridges known as Gable Mountain and Gable Butte, which run easterly and westerly, complete the topographic interruption. Unstabilized sand dunes occur as scattered islands of various sizes ranging from an acre to several thousand acres. The largest and most extensive unstabilized dune complex occurs along the west bank of the Columbia River opposite Ringold.

The vegetation is dominated by desert shrubs and characterized by big sagebrush, bitterbrush, rabbit-brush, and spiny hopsage. The understory consists of a generally sparse layer of grasses and forbs; primarily important are Sandberg bluegrass and cheatgrass. Bluebunch wheatgrass, especially in the Rattlesnake Hills, is an important contributor to ground cover at elevations above 900 feet. Trees occur erratically along the banks of the Columbia River, along gullies and water courses in the Rattlesnake Hills and at scattered locations throughout the reservation where they have been planted as shade around industrial buildings. A few scattered trees, survivors of orchards abandoned 30 years ago are present in the vicinity of the abandoned townsites of Hanford and White Bluffs.

The natural vegetation mosaic has been scarred by numerous fires and by past agricultural practices; particularly noticeable are abandoned 
agricultural fields dominated by cheatgrass and annual mustards. Other anthropogenic impacts to vegetation are the many miles of roadways and railroads, adjacent barrow pits, and maintenance roads that parallel electrical power lines.

The waste waters from chemical processing facilities located in the central part of the Reservation have created the Gable Mountain, B, $U$ and West ponds. Over the years, aquatic vegetation has developed in these ponds with typical emergent plants such as cattail and bulrush invading the shallow waters along the pond margin. In some instances willow and cottonwood trees have also become self-established.

The mammalian species of the Hanford Reservation have broad, geographic distributions that extend throughout the semi-arid regions of the Pacific Northwest. None is indigenous to the state of Washington nor regarded as rare or endangered by the U.S. Fish and Wildlife Service. The local distribution of mammals is more dependent upon combinations of abiotic and biotic factors that constitute suitable habitat rather than geographic boundaries. For the most part, two broad mammalian habitat categories are recognized: (1) the shrub-steppe habitat. This habitat consists of soil substrate, the prevailing climatic regime, and food base and shelter as provided by sagebrush, associated shrubs and herbaceous species; and (2) riparian (streamside) habitats with or without adjacent permanent surface water which provides succulent, green vegetation during summer months. For the most part, riparian vegetation consists of deciduous trees and shrubs, especially willow, Salix spp, and a rich mixture of perennial grasses and forbs not associated with dryland-steppe vegetation.

This document describes the important mammalian species inhabiting the Hanford Reservation and their known or inferred relationships to Waste Management areas. 
BNWL-1877

\section{MAMMAL SPECIES}

Twenty-five mammals, exclusive of bats, can be expected on the Hanford Reservation. These are listed according to phylogenetic sequence in Table 1. The nomenclature is that presented by Ingles (1965), "Mammals of the Pacific States." A grouping of mammals according to frequently used habitat-types, food habits and size class is shown in Table 2. For convenience, mammals are discussed as herbivores and carnivores.

Accurate estimates of population densities and home ranges of mammals are time consuming and expensive to perform. The most reliable estimates available for the Hanford Reservation are those associated with live trapmark-recapture studies with sedentary pocket mouse populations. Mobile mammals are often wary, travel great distances and often show seasonal patterns of movement over large landscape areas. Radio transmitters offer the best means of circumscribing home ranges for these kinds of mammals. This study does not address population densities or home ranges per se but presents only relative abundance and general ecological distribution patterns. 
TABLE 1. Mammals of the Hanford Reservation

Family

Soricidae

Leporidae

Sciuridae

Geomyidae

Heteromyidae

Castoridae

Cricetidae

Muridae

Erethizontidae

Canidae

Procyonidae

Mustelidae

Felidae

Cervidae $\underline{\text { Scientific Name }}$

Sorex vagrans

Lepus californicus Sylvilagus nuttallii

*Citellus townsendi

Thomomys talpoides

Perognathus parvus

Castor canadensis

Reithrodontomys megalotis Peromyscus maniculatus Onychomys leucogaster

Neotoma cinerea

Lagurus curtatus

Microtus montanus Ondatra zibethica

Rattus norvegicus Mus musculus

Erethizon dorsatum

Canis Tatrans

Procyon lotor

Mustela vison

Mustela frenata

Taxidea taxus

Mephitis mephit is

Lynx rufus

Odocoileus hemionus

\section{Common Name}

Vagrant shrew

Black-tailed hare

Nuttall cottontail

Townsend ground squirrel

Northern pocket gopher

Great Basin pocket mouse

Beaver

Western harvest mouse

Deer mouse

Northern grasshopper mouse

Bushy-tailed wood rat

Sagebrush vole

Montane meadow mouse

Muskrat

Norway $r$ at

House mouse

Porcupine

Coyote

Raccoon

Mink

Long-tailed weasel

Badger

Striped skunk

Bobcat

Mule deer

*Spermophilus townsendi 
TABLE 2. Mammals grouped according to habitat-type, food habits and size classes

HABITAT-TYPE

Shrub-steppe

Black-tailed hare

Great Basin pocket mouse

Deer mouse

Grasshopper mouse

Sagebrush vole

Bushy-tailed wood rat

Western harvest mouse

Cottontail

Badger

Northern pocket gopher

\section{Riparian-aquatic}

Muskrat

Beaver

Raccoon

Mink

House rouse

Montane meadow mouse

Vargrant shrew

Porcupine

Shrub-steppe and Riparian

Mule deer
Coyote
Bobcat
Striped skunk
Weasel

Mule deer

Striped skunk

Buildings and Caves

Bats

Norway rat
FOOD HABITS

SIZE CLASSES

Large Mammals

Mule deer

Mule deer

Great Basin pocket mouse

Muskrat

Beaver

Western harvest mouse

Sagebrush vole

Black-tailed hare

Cottontai

Bushy-tailed wood $r$ at

Porcupine

Townsend ground squirrel

Northern pocket gopher

Montane meadow mouse

House mouse

Norway $r$ at

Insectivores

Deer mouse

Vagrant shrew

Grasshopper mouse

Bats

\section{Carnivores}

Coyote
Striped skunk
Weasel
Badger
Raccoon

Coyote

Weasel

Racco

\section{Medium Mammals}

Coyote

Beaver

Porcupine

Bobcat

Raccoon

Badger

Striped skunk

Black-tailed hare

Cottontai 1

Muskrat

\section{Sma11 Mamma1s}

Mink

Norway $r$ a t

Townsend ground squirrel

Long-tailed weasel

Bushy-tailed wood $r$ at

Northern pocket gopher

Montane Meadow mouse

Sagebrush vole

Grasshopper mouse

Deer mouse

House mouse

Great Basin pocket mouse

Western harvest mouse

Bats

Vagrant shrew 
BMWL- 1877

\section{HERBIVOROUS MAMMALS}

\section{MULE DEER}

Ecological Distribution

The mule deer is the only big-game mammal found on the Hanford Reservation. Although deer can be expected to occur anywhere, major concentrations occur along the Columbia River between the abandoned townsite of Hanford and the B-C reactor area. Smaller concentrations occur in the Gable Mountain and Gable Mountain pond area and in the Rattlesnake Hills (Figure 1). The Columbia River is not necessarily a barrier to the movement of deer. In fact, Columbia River islands are a major fawning area. Barbed wire fences that restrain livestock are also not a barrier to deer. Adult deer, in good health, easily jump 4-foot high barriers; however, if the lower strand of barbed wire fences is more than 18 inches high, deer may elect to crawl beneath the lowest wire. Chain-link fences, eight or more feet in height, would provide effective barriers to deer if gates were kept closed.

Mule deer are wanderers. Ordinary migrating patterns include movement from summer ranges, located high in the mountains, to winter ranges located in the foothills and plains. Mule deer tagged as fawns on the Hanford Reservation have been killed by hunters as far away as Mattawa, Prosser, and Wallula Junction (Hedlund, et al., 1974). Deer can be a nuisance to traffic as they often cross highways and occasionally are hit by fast-moving vehicles. The problem is most acute during nighttime hours and during autumn months. Mule deer provide important esthetic value to an otherwise generally drab landscape.

Reproduction

Mule deer drop one or two, and occasionally three fawns in June. The rutting season is during early autumn, October-November. During the rutting season mule deer males are fully antlered and the neck enlarges, lending a thick-necked appearance to the animals at this time of year. Antlers are dropped in February and March and usually new antler growth is visible by May or June. 


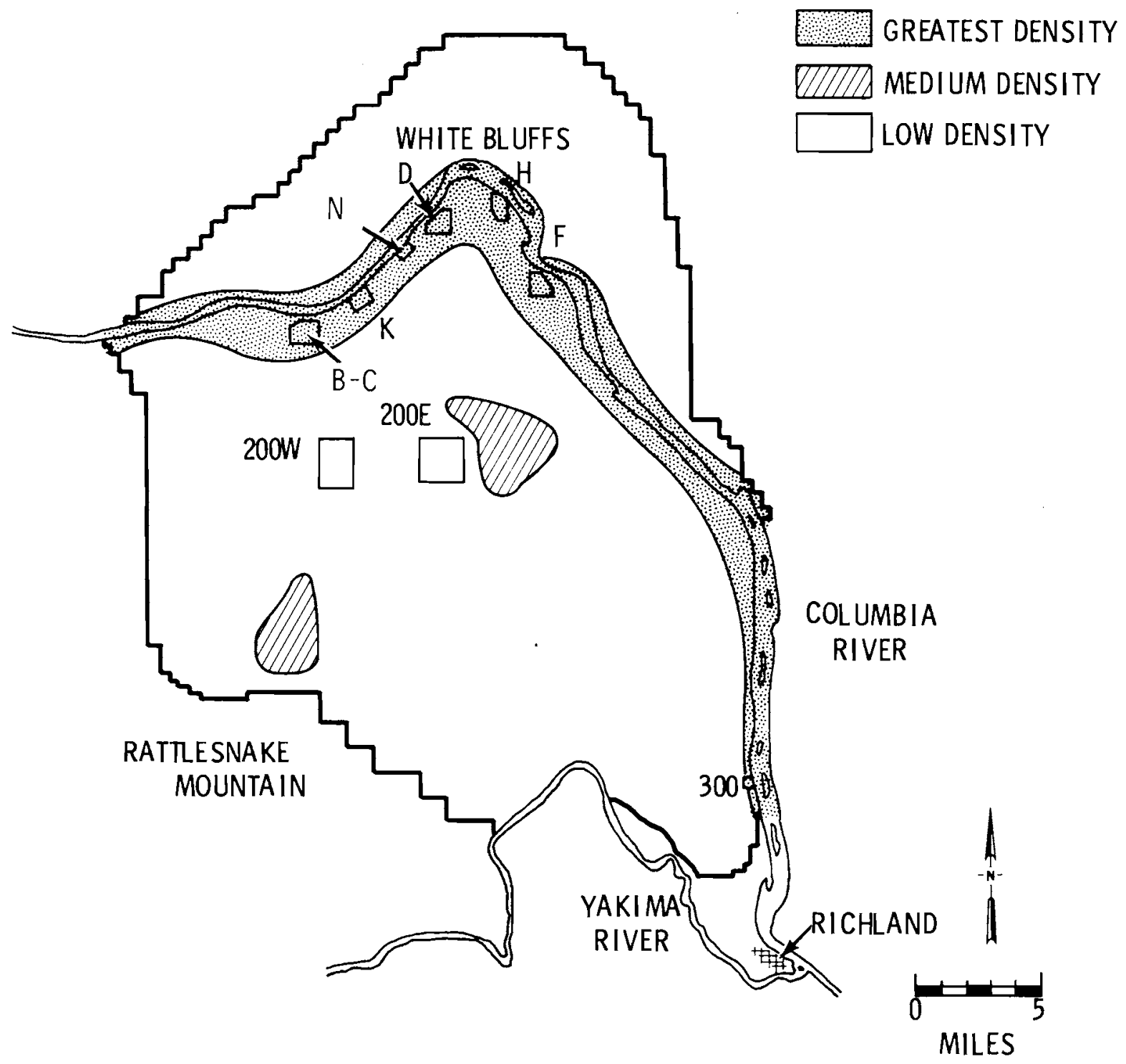

FIGURE 1. Ecological distribution of mule deer on the Hanford Reservation. 
$\underline{\text { Food }}$

Mule deer eat a variety of plants. Important food items are the browse, supplied by streamside willows in summer and bitterbrush in winter. Mule deer also feed upon Sandberg bluegrass, cheatgrass and a wide variety of forbs, incl uding the annual mustards and Russian thistle.

Predators

The major predators are the bobcat and coyote which kill a number of fawns each year. Coyotes have been observed to team-up to kil1 adul t deer. During hunting season, a sma 11 number of adult deer are harvested from areas adjacent to the reservation and a few are killed by automobiles each year.

$\underline{\text { Pest Relationships }}$

Mule deer are pests to young ornamental trees planted at the WPPSS steam-electric plant. This necessitated the installation of wire screen protection 4-5 feet above ground level. Most other trees growing on the Hanford Reservation have well-defined browse lines with most leaves elevated beyond the reach of the average deer.

\section{$\underline{\text { BLACK-TAILED HARE }}$}

$\underline{\text { Ecological Distribution }}$

The black-tailed hare (jackrabbit) is the most abundant leporid on the Hanford Reservation. It can be found anywhere in the shrub-steppe habitat; however, it has seldom been observed at elevations above 1200 feet in the Rattlesnake Hills, especially where bluebunch wheatgrass is a dominant feature of the vegetation. In the past, concentrations of hares have been noted in the vicinities of Rattlesnake Springs, B-C Crib area and the areas adjacent to and north of Gable Mountain. In the late 1940's and during the 1950's, hares were a useful biological monitor of the environmental distribution of ${ }^{131} \mathrm{I}$. In the 1960's, hares were identified by the waste management contractor as the biologic agent responsible for the dispersion of ${ }^{137} \mathrm{CS}$ and ${ }^{90} \mathrm{Sr}$ in the $\mathrm{B}-\mathrm{C}$ Crib area. The hare is an important dietary item of the coyote and golden eagle, especially during winter when eagles regularly use the Hanford area as foraging territory. 


\section{Reproduction}

Black-tailed hares breed year-round. Young are born above ground with up to seven per litter.

Food

Hares eat a variety of plants. The tender twigs of sagebrush, which are selected while its leaves are discarded, are one of the hare's basic foods. Although more work needs to be done regarding the dietary habits of hares in waste management zones, preliminary observations at Hanford and studies done in the plains of Colorado indicate that cheatgrass, an abundant grass in the B-C Crib area, is not an important dietary item. Hares do not require drinking water to sustain themselves. Even under the most persistent conditions of summer drought, water can be extracted from vegetation eaten as food.

In contrast with the cottontail, the black-tailed hare is coprophagous. Two kinds of fecal pellets are produced; a hard, normal waste pellet formed in the intestine in the usual way, and a softer pellet formed in the caecum and reingested directly from the anus.

\section{Predators}

Hares are regarded as a game animal in the state of Washington and a hunting license is required. Although the flesh is edible, hares are seldom eaten by local hunters who shoot them mostly for sport. Besides man, predators include raptors, snakes, coyotes, and bobcats.

Hares are commonly observed as road-kills along the major Hanford highways. Dead animals are eaten by coyotes, badgers, ravens, magpies, and sometimes hawks and eagles.

\section{Pest Relationsh ip}

Hares can be a pest to new plantings of grass, orchard trees, and alfalfa. Such plantings, especially in the succulent stages of seedling development, can attract large numbers of hares if not controlled. 
BNWL-1877

COTTONTAIL RABBIT

Ecological Distribution

The cottontail rabbit is probably more abundant than sightings would indicate. Unlike the hare, the cottontail spends time below ground utilizing burrows made by badgers or seeking shelter beneath piles of debris, such as culverts, stacks of fence posts, foundations of abandoned farmsteads, and out-buildings. Cottontails can be expected to occur anywhere in the shrub-steppe habitat where burrows and protective cover are available. The cottontail is regarded as a game animal and the meat is edible and a highly regarded food. The cottontail is easily differentiated from the hare; adult cottontails being about half the size of adult hares. The ears of cottontails are relatively short and are about the same length as the head, while the ears of the hare are longer than the head. The tail of the cottontail is pure white, and, in contrast, the upper (dorsal) surface of the black-tailed hare is coal-black.

\section{Reproduction}

Young are produced in early summer with as many as 7-8 per litter. $\underline{\text { Food }}$

Cottontails are herbivores, feeding on the seasonally available herbs and shrubs.

Predators

Cottontails are seldom seen as road-kills on the Hanford Reservation, partly because they do not range as far afield as do hares. Cottontails are prey for raptors, snakes, coyotes, badgers, skunk, mink, raccoon, and bobcat.

Pest Relationships

Cottontails are not known to occur in such large numbers as to be a serious pest to agricultural plants which is the case for black-tailed hares. 
BEAVER

Ecological Distribution

Beavers are highly aquatic mammals, spending most of their lives in or adjacent to permanent ponds or streams. However, at times beavers have been known to travel long distances overland. Beavers have not been observed in any of the ponds in the 200 Areas. There are active colonies along the Columbia River, especially in places with quiet backwaters, such as upstream from the White Bluff ferry landing and abandoned townsite of Hanford. The presence of beavers is evident by the characteristic teeth marks on tree trunks and stumps.

\section{Reproduction}

Young are born in April and May with 3-6 kits per litter. Both parents remain with the young.

Food

Beavers are vegetarians. Their diet consists of tree twigs, leaves of deciduous trees, bark, and succulent green plants.

Predators

Young beaver are subject to predation by coyotes, bobcats, and perhaps raccoons. Adults are not likely to be preyed upon because of their large size. Beavers are the largest rodent in North America with adults weighing up to 74 pounds. Beaver are trapped for fur. A Washington State fur-trapping license is required in season.

\section{Pest Relationships}

Beavers can be pests in irrigation canals by constructing dams and digging into levies and dikes. In time, they can be expected to appear in ponds in the 200 Areas. 
BNML-1877

\section{MUSKRAT}

\section{Ecological Distribution}

Muskrats are not quite as aquatic as beavers. Although surface water is required, muskrats live in small streams and shallow ditches that would not be acceptable to beavers, Muskrats are common along the Columbia River, particularly in the quiet backwater areas. Muskrats have been observed in ponds and ditches in the 200 Areas and at Rattlesnake Springs.

\section{Reproduction}

Young are born in the spring or sumer with 3-9 per litter.

Food

Muskrats eat a variety of succulent plants commonly found in aquatic habitats. They do not cut trees as do beavers and are much smaller than beavers.

Predators

Muskrat predators are the coyote, bobcat, great horned owl, and the larger hawks. Muskrats are regarded as fur-bearers in the state of Washington and a license is required for trapping in season. Muskrat meat is edible although seldom eaten by people.

\section{Pest Relationships}

Muskrats are important in waste zones because they frequently contact pond sediments and thus have the opportunity to ingest or become contaminated by radioactive debris associated with sediments and vegetation. Although muskrats are sedentary and seldom travel great distances overland, their predators however, have the ability and opportunity to travel far from waste management zones and of $f$ the Hanford Reservation. 
BMML-1877

\section{PORCUPINE}

\section{Ecological Distribution}

Porcupines are found in riparian habitats and in the abandoned orchards along the west bank of the Columbia River, especially between the abandoned townsite of Hanford and the 100-D Area. They are particularly conspicuous in early spring when they climb high into trees and feed upon the new buds and bark of Siberian elms, white poplar, and cottonwood. They have been observed at U-pond in the 200 West Area and in the Snively Gulch area in the Rattlesnake Hills.

\section{Reproduction}

Normally only one young is born per year. Gestation is about 209 days and the young are born in the spring.

Food

The food of porcupines consists of twigs, leaves, buds and bark of deciduous trees and various herbs associated with riparian habitats.

\section{Predators}

Although well protected by sharp spines, porcupines can be killed by bobcats.

\section{Pest Relationships}

Porcupines are not regarded as game animals or fur bearers. Porcupines can be a pest to newly planted trees by eating bark and small twigs.

\section{GREAT BASIN POCKET MOUSE}

Ecoloaical Distribution

Pocket mice are the most abundant and most studied mammal on the Hanford Reservation. They can be expected anywhere in the shrub-steppe habitat; however, they are more abundant at low elevations than at high elevations. They prefer open, shrub-dominated vegetation with a sparse herb understory 
of cheatgrass and Sandberg bluegrass. Pocket mice are burrowing animals, spending more time below ground than above. They are nocturnal and are periodically torpid during the heat of summer and cold of winter.

$\underline{\text { Reproduction }}$

Pocket mice breed in the spring. Males characteristically emerge in early spring before females. Young usually appear in the trap catches in mid-summer. In favorable moisture years, two litters may be produced. These animals are not wanderers and tend to stay within territories near their burrows. O'Farrell, et al, (1974), during a four-year study, estimated home ranges to be from $1560-4005 \mathrm{~m}^{2}$ for males and 503-2301 $\mathrm{m}^{2}$ for females. The wide fluctuations were dependent upon population density and food availability.

$\underline{\text { Food }}$

Pocket mice are seed eaters, and especially feed on the seeds of cheatgrass. These mice have external fur-lined cheek pouches in which seeds are carried from the collection site to burrows or caches. They do not require free water to drink and can, instead, sustain themselves upon food as a source of water. The bioenergetics of pocket mice populations in shrub-steppe regions is the subject of a doctoral dissertation (Schreiber, 1973). Pocket mice frequently take dust baths to clean their fur. This is a potential means for ingestion of soil-adherent radionuclides.

\section{Predators}

Pocket mice are preyed upon by all classes of raptors, and snakes, and a11 sizes of mammalian predators, except the shrew (see Table 3 ). These animals are an important food base for all vertebrate predators.

\section{$\underline{\text { Pest Relationships }}$}

Pocket mice are not regarded as pests. 


\section{TOWNSEND GROND SQUIRREL}

Ecological Distribution

Townsend ground squirrels are abundant and occur in loosely organized colonies throughout the steppe habitat. They are active in daylight hours during the most active part of the plant-growing season--March to June.

The rest of the year is spent below ground in burrows. In terms of biomass, ground squirrels are often the most important small mammal. Colonies of ground squirrels in waste management zones can be expected to attract mammalian predators such as the coyote and badger.

\section{Reproduction}

Townsend ground squirrels have young once each year with a probable litter size of $4-5$.

Food

Ground squirrels are herbivorous, feeding mainly on new growth shoots of grasses and forbs.

\section{Predators}

Ground squirrels are important items in the diets of mammalian carnivores and also contribute to the diet of raptorial birds.

\section{Pest Relationships}

Townsend ground squirrels are important to waste management because of their burrowing habits and attraction to predators when populations are high.

\section{MONTANE NEADOW MOUSE}

Ecological Distribution

The montane meadow mouse is seldom encountered in shrub-steppe habitats. They are abundant in dense, herbaceous vegetation associated with riparian habitats. In time, populations can be expected to increase in the vicinity of waste ponds as rank, herbaceous vegetation becomes more abundant along pond shores and ditches. 
The meadow mouse has not been recorded in the 200 Areas, but its presence could probably be verified by a special trapping survey.

\section{Reproduction}

Litter size ranges from 4-8 with litters being produced in the spring. Food

Food consists of succulent stems and leaves of forbs not grasses. Montane meadow mice cut runways through grassy swards and make nests of dead grass underground.

Predators

Montane meadow mice are prey for all classes of mammalian predators, raptors, and snakes.

\section{Pest Relationships}

When abundant, these animals can be a pest in alfalfa fields.

\section{WESTERN HARVEST MOUSE}

\section{Ecological Distribution}

The harvest mouse is the smallest mouse on the Hanford Reservation. It is uncommon in steppe vegetation. Only a few records of harvest mouse catches have been made over the many years of mammalian trap studies. Catches have been recorded from Rattlesnake Springs, especially from dense grass stands.

\section{Reproduction}

Young are born throughout the year with 4-6 per litter.

Food

Seeds are believed to be a major dietary constituent.

\section{Predators}

The predators of harvest mice are raptors, snakes, and all classes of mammalian predators.

\section{Pest Relationships}

The harvest mouse is not regarded as a pest. 


\section{HOUSE MOUSE}

Ecological Distribution

The house mouse is a prolific rodent introduced from Eurasia. This mouse generally is thought to live in association with human habitation, but is found on occasion in riparian vegetation on the Hanford Reservation. Very rarely have house mice been captured in the shrub-steppe habitat, but they are commonly found in the reactor areas and in the 200 Area buildings. Reproduction

Under ideal conditions, house mice may have 5 litters of 4-8 young per year.

Food

House mice are omnivorous, eating seeds, fruits, vegetables, insects, and meat.

\section{Predators}

House mice are preyed upon by all predators, although because of their speed and secretive behavior they are difficult to capture.

\section{Pest Relationships}

House mice often infest grain storage areas and, where conditions are conducive to reproduction, a population may reach plague proportions.

\section{NORTHERN POCKET GOPIER}

\section{Ecological Distribution}

Pocket gophers are found throughout the shrub-steppe habitat. They are almost completely fossorial, spending little time above ground. The most dense populations probably occur in the abandoned agricultural fields in the Rattlesnake Hills. The presence of small earth mounds without apparent burrow openings are the work of pocket gophers who characteristically plug burrow entrances with earth. 


\section{Reproduction}

Pocket gophers produce many young each year. The average litter size is 5 or 6 .

Food

Pocket gophers eat a variety of plants. Above and below ground plant parts are eaten.

Predators

Pocket gophers are preyed upon by coyotes, badgers, weasels, snakes, and raptors.

\section{Pest Relationships}

Pocket gophe'rs mine much soil each year through their burrowing habits. The burrow system of a mature animal may encompass 200 square feet. Pocket gophers can be destructive to agricultural crops when populations are high.

\section{SAGEBRUSH VOLE}

Ecological Distribution

The sagebrush vole does not regularly occur in the waste management zones. Populations are most abundant at medium and high elevations in the Rattlesnake Hills.

\section{Reproduction}

Sagebrush voles are frequently found in colonies and burrow 4-8 inches deep. Litters range from 1-11, averaging about 5 .

Food

The animals are herbivorous and eat the leaves of sagebrush plants as well as green succulent vegetation from which they derive water. The animals do not need to drink. Like other kinds of microtines, the sagebrush vole is active during daylight hours. 


\section{Predators}

The sagebrush vole is preyed upon by mammalian predators, raptors, and snakes.

\section{Pest Relationships}

The sagebrush vole is not an important agricultural pest. The sagebrush vole population is of interest to public health because it is believed to be the source of the fleas that carry sylvatic plague.

DEER MOUSE

\section{Ecological Distribution}

The deer mouse is ubiquitous, occurring in steppe and riparian habitats, Next to the pocket mouse, the deer mouse is the most abundant mammal on the Hanford Reservation. It is more abundant in high altitude, steppe habitats than the pocket mouse.

\section{Reproduction}

Deer mice breed in the winter and early spring. Embryos average 5 and the gestation period is 21 to 27 days. Young are able to breed 6-7 weeks following birth.

Food

The deer mouse accepts a greater variety of foods than the pocket mouse. It eats plant parts and invertebrates.

\section{Predators}

Deer mice are preyed upon by all classes of mammalian predators, snakes, and raptors.

\section{Pest Relationships}

Although abundant, deer mice are seldom seen by people because of their nocturnal habits. They are not regarded as pests. Deer mice are clean and dainty. They thrive under laboratory conditions and are suitable for laboratory studies of physiology and genetics. 


\section{BUSHY-TAILED WOOD RAT}

Ecological Distribution

Wood rats are thinly dispersed over the Hanford Reservation and are usually associated with rocky crevices in the Rattlesnake Hills and the Gable Mountain areas. They also occupy abandoned buildings. The tail of wood rats is covered with hair long enough to obscure the scales beneath, in contrast to the Norway $r a t$ which has a scaley tail.

\section{Reproduction}

Litter size ranges from 3-4 and the young are born in early spring. Gestation period is between 23 and 38 days.

Food

Wood rats feed mainly on plant material.

\section{Predators}

Wood rats are mostly active during daylight hours and are preyed upon by raptors, coyotes, and the larger snakes.

\section{Pest Relationships}

Wood rats build "houses" by piling sticks and stones and debris, such as paper and metal objects, and often occupy unused buildings.

\section{NORWAY RAT}

\section{Ecological Distribution}

Norway rats were introduced into North America from Europe. Although they are mostly confined to buildings used by people, they occasionally are found in fields far removed from buildings. For example, one was trapped in steppe vegetation on the Arid Lands Ecology reserve.

\section{Reproduction}

Norway rats breed when 3-4 months old and have litters of 6 to 22 . The gestation period is 22 days. 
$\underline{\text { Food }}$

Foods include unattended or uncovered residues of human and pet foods, livestock feed, stored grains and probably some wild seeds.

Predators

Owls, particularly the great horned owl, and the coyote are the most likely predators.

Pest Relationships

Norway rats carry some diseases of humans and livestock including trichinosis, rabies, tuleremia, Salmonella food poisoning, typhus and bubonic plague. They can also damage stored livestock forage and human food i tems.

\section{CARNIVOROUS MAMMALS}

COYOTE

Ecological Distribution

The coyote is the most abundant, widespread and most important mammalian predator on the Hanford Reservation. Coyotes are the major factor in causing Canada geese to abandon nests on Columbia River islands.

The role of the coyote in food webs a t waste management sites is clearly that of a top level consumer. Adults have the ability to travel far from waste management zones. This is important from the viewpoint of radionuclide transfers along food chains and the distance of radionuclide dispersal through fecal and urinary deposits.

\section{Reproduction}

Coyotes make their dens in natural crevices but they can enlarge burrows made by other animals, such as badgers. In early spring they have a litter which averages 6 or 7 pups. 
$\underline{\text { Food }}$

Coyotes eat a great variety of plants and animals. They prey upon small mammals, cottontails, black-tailed hares, lizards, snakes, birds, insects, especially darkling beetles and grasshoppers, and also eat dead rabbits on the road. Coyotes can kill mule deer fawns and occasionally an adult deer. In waste management areas they prey upon waterfowl and eat dead fish that have washed ashore. Coyote control is not practiced in the Hanford Reservation unless specifically requested.

\section{Predators}

Coyotes have few predators, man being the most important.

\section{Pest Relationships}

As a rule, livestock growers regard coyotes as a threat to lambs and calves. They cite instances where substantial economic losses have occurred as a result of coyote predation. Others regard the coyote as a rightful member of the ecological community and desire its protection against possible extinction by aggressive predator control campaigns, especially chemical poisons. Some regard the coyote as an ecological asset by playing important roles in rodent and hare population control.

\section{BADGER}

\section{Ecological Distribution}

Badgers are sparingly represented on the Hanford Reservation. They occur throughout the shrub-steppe habitat and can be encountered in riparian vegetation although they are not aquatic. Badgers are noted for their diggings abilities. The steppe habitat is scarred by their burrows, circular holes 8-10 inches in diameter with characteristic mounds of earth at the entrance. Adult badgers are aggressive and offer a strong defense when threatened. The badger is the most important mammal in relation to dry 
buried waste. Because of their digging abilities, badgers can dig into backfill and expose buried material. A badger is believed to be the animal responsible for digging into waste burial sites in the $B-C$ Crib Area.

$\underline{\text { Reproduction }}$

Young are born in spring with 2-5 per litter and are tended by the fema 1e.

Food

Badgers are strongly carnivorous. They eat birds and small mammals, chiefly Townsend ground squirrels.

\section{Predators}

Adult badgers have no known predators except man and are trapped for their fur.

\section{Pest Relationships}

Because badgers dig holes in the earth, a potential danger exists to running cattle and horses such as the possibility of broken legs. Otherwise, badgers are regarded as beneficial because of the number of rodents they destroy each year.

\section{BOBCAT}

\section{Ecological Distribution}

The bobcat is present on the Hanford Reservation in small numbers. Sightings are infrequent because of the nocturnal habits and wariness. Bobcats have been seen on Columbia River islands and several locations in the Rattlesnake Hi11s, i.e., ALE headquarters, Rattlesnake Springs and Snively Gulch. They also have been sighted in the vicinity of U-pond.

\section{$\underline{\text { Reproduction }}$}

Young are born in the spring, generally April, and average 3 per litter. 
Food

Bobcats are more exclusively carnivorous than coyotes. They feed upon birds, small mammals and rabbits and have been known to kill mule deer fawns, calves and lambs. The bobcat is of less concern as a top trophic level consumer than the coyote because of the generally low population.

Predators

The bobcat is a medium-sized mammal, averaging between 15 and 20 pounds in weight. They have no known predators as adults, except man, and possibly the coyote. They are regarded as fur-bearers in the state of Washington and a license is required for shooting or trapping in season.

Pest Relationships

Bobcats are known to kill young sheep and occasionally young calves.

\section{RACOOON}

\section{Ecological Distribution}

The raccoon is nocturnal. Raccoons are mostly found in the riparian vegetation along the Columbia River and along the ponds in the 200 Areas. The raccoon is a highly adaptable mammal and readily accommodates to human activities.

\section{Reproduction}

Young are born in early spring with 2-7 per litter. The gestation period is 9 weeks.

\section{Food}

Raccoons eat a variety of plant and animal foods associated with the riparian habitat, i.e., fish, crayfish, clams, garter snakes, frogs, birds and small mammals. The presence of raccoons can be verified by the characteristic tracks they leave in the muddy zones along the edges of ponds, ditches and streams. Like the muskrat, the raccoon has access to pond sediments which can be ingested along with food items. 


\section{Predators}

Raccoons are medium-sized mammals. Adults usually weigh 10-15 pounds. They have no known active predator on the Hanford Reservation. Raccoons are trapped for their fur on off-reservation lands. A state fur-trapping license is required for the trapping of raccoon in season.

\section{Pest Relationships}

Raccoons have been pests by rummaging through garbage containers in the 100 Areas as they are good climbers and readily scale chain link fences, trees and buildings. They have been reported to cause electrical power outages by climbing onto and short-circuiting electrical wires. Raccoons are deceptively docile in appearance, however, when threatened they can be vicious.

MINK

\section{Ecological Distribution}

Mink are present on the Hanford Reservation in riparian habitats. They may be more abundant than sight records indicate because of the nocturnal habits and general wariness. Mink probably occur around waste ponds in the 200 Areas. One road-killed animal was observed in Snively Gulch in the Rattlesnake Hills.

\section{Reproduction}

Young are born in litters of 5 or more with a gestation period of 38-85 days, depending on when they were bred.

Food

Mink, while commonly found near aquatic habitats, can range far distances over land. They eat fish, crayfish, frogs, mice, rabbits, muskrats, coots, ducks, and even dead animals. 


\section{Predators}

Mink are strong animals for their size. Adults weigh about 3 pounds. Their main predators are probably the great horned owl and the larger hawks, especially the marsh hawk.

\section{Pest Relationships}

Although mink can be destructive to poultry, they are not abundant enough to be regarded as pests.

\section{STRIPED SKUNK}

\section{Ecological Distribution}

Skunks can be expected anywhere on the Hanford Reservation, but mostly in the riparian habitats. Skunks are probably more abundant than sighting indicates, being nocturnal they are subject to road kill. Road-killed skunks are seldom seen on Hanford Reservation roads because of the low number of road miles passing through or near riparian habitat.

\section{Reproduction}

Four to seven young (average 5) are born in the spring after a gestation period of 63 days.

\section{Food}

Skunks are omnivorous, eating a variety of plant and animal foods as they become available seasonally.

\section{Predators}

The scent glands, with strongly malodorous secretions, are purposeful deterrents aginst predators. The only known predator is the great horned owl. Skunks are trapped for their fur.

\section{Pest Relationships}

A7though skunks can be a pest to poultry raisers, they are usually regarded as beneficial because they destroy small rodents and insects. 


\section{GRASSHOPPER MOUSE}

Ecological Distribution

Grasshopper mice are uncommon in the Hanford Reservation. They occur in small numbers throughout the steppe habitat. These are the most carnivorous of mice and have been the object of scientific attention because of a relatively long-1ife span for a small mammal.

\section{Reproduction}

Three to six young are born after a gestation period of 5 weeks.

Food

Up to 90 percent of their food can be of animal origin and much of it is arthropods, such as grasshoppers. Grasshopper mice also eat seeds, beetles, and occasionally lizards. They are nocturnal and live in a burrow, generally one which has been deserted by another mammal.

\section{Predators}

Grasshopper mice are preyed upon by raptors, mammalian predators and snakes.

\section{$\underline{\text { Pest Relationships }}$}

These mice are too scarce to be regarded as pests.

\section{VAGRANT SHEN}

\section{Ecological Distribution}

Shrews have been reported from only a few locations on the Hanford Reservation. However, they are likely to be more abundant in riparian rather than steppe habitats.

\section{Reproduction}

Shrews may breed twice a year. Litter sizes vary between 2 and 9. The young weigh one-half gram at birth with an adult weight of 6-7 grams. 
$\underline{\text { Food }}$

Shrews are known to eat immature and adult insects.

Predators

Unknown.

Pest Relationships

Shrews are seldom seen, although they are often active during daylight hours. They are not regarded as pests.

\section{LONG-TAILED WEASE}

Ecological Distribution

Weasels are scarce on the Hanford Reservation. Most records are associated with small mammal trap studies done in the Rattlesnake Hills, but they probably occur in riparian habitat along the Columbia River and around ponds and ditches in waste management zones.

\section{Reproduction}

Mating occurs in July to August, usually a single litter is produced consisting of 6-9 young the following spring.

Food

A weasel can eat 40 percent of its body weight in food each day. Its food consists mostly of small rodents and sometimes rabbits and birds. The weasel is extremely quick and can climb.

\section{Predators}

Weasels are active day and night. Important predators are hawks and owls.

Pest Relationships

Occasionally weasels are reported as pests in poultry pens where they can kill chickens. They are an important means of rodent control in wild and agricultural situations. 


\section{MAMMALS OCCASIONALLY OBSERVED ON THE HANFORD RESERVATION}

The Yakima firing range immediately north and west of the Hanford Reservation supports a small resident herd of pronghorn antelope, Antilocapra americana. These animals have been sighted in the Rattlesnake Hills but not on the Hanford Reservation property.

White-tailed deer, Odocoileus virginianus, have been reported on the Hanford Reservation (O'Farrell and Hedlund, 1972).

A single female elk, Cervus canadensis, has been sighted on the Hanford Reservation, apparently a stray from the Blue Mountains since the animal crossed the Columbia River in the vicinity of the 300 Area. Subsequent tracks and sightings occurred in Snively Basin, Rattlesnake Springs, Yakima Ridge and Redox Pond in the 200 Area.

The least chipmunk, Eutamias minimus, has been trapped on several occasions on the ALE Reserve.

Bats may be more important than sight records indicate. The mammal collection at the ALE headquarters building shows only three species. These are little brown rnyotis, Myotis lucifugous; hoary bat, Lasiurus cinereus; and silvery-haired bat, Lasionycteris noctivagans.

The Ord kangaroo rat, Dipodomys ordii, is common in steppe vegetation on sandy soil south of the Columbia and Snake rivers, but has not been recorded from the Hanford Reservation. The yellow-bellied marmot, Marmota flaviventris, occurs along the breaks of the Snake River in Walla Walla County, but has not yet been sighted on the Hanford Reservation. 
BNWL-1877

\section{IMPACT OF MAMMALS ON PLANT COMMUNITIES}

Domestic livestock, particularly sheep and cattle, have played important roles in altering plant communities on the Hanford Reservation, particularly in the years prior to 1943 when the Hanford Reservation was acquired by the government. The spread of cheatgrass throughout the vegetation mosaic on low elevation areas is attributed in part to the herds and flocks of cattle and sheep that grazed over the Hanford area. These animals disturbed the native plants and soil-lichen-algae crusts and created a microhabitat favoring the establishment of cheatgrass over native species weakened by persistent grazing.

The absence of a resident human population, the lack of grazing livestock, and the refuge from hunting provided by the security programs on the Hanford Reservation over the past 30 years have permitted mule deer populations to increase greatly over pre-reservation populations. During pre-reservation days, deer populations were purposefully kept at low levels because of the damage they could cause to fruit trees. The deer population at Hanford is particularly vulnerable to hunting because of the scarcity of dense vegetative cover and generally level terrain. Under protection from hunting the deer population appears to be in short supply of green succulent browse plants, especially in summer. These kinds of plants occur mostly along the banks of the Columbia River and its islands and show heavy browsing use by deer. 


\section{FENCES AS BARRIERS TO MAMMALS}

The construction of a chain-link fence ( 8 feet high) around the entire waste management area would be a barrier to the movement of certain mammals. The expected impact of such a fence and suggested management practices applicable to important species are described in the following paragraphs.

\section{POCKET MICE AND GROUND SQUIRRELS}

Because these animals burrow and are small, an ordinary chain-link fence is not a barrier. A partly buried fence of small mesh wire would be an effective barrier to movement but raptors would still have access to the population. Research strategies here are to experiment with barriers placed in burial trenches to restrict their digging into buried waste. The barriers might consist of gravel layers, for example.

\section{COYOTES AND BADGERS}

A partly buried chain-link fence could provide a strong barrier to movement of coyotes although badgers are able to burrow several feet deep and thereby by-pass the fence as a barrier. However, it is likely that such a fence would deter access most of the time. An alternative to fencing is an intensive research effort on the life history, behavior and radionuclide metabolism of coyotes and badgers.

\section{MUSKRAT AND RACOOON}

The muskrat is already established in some waste ponds and ditches. The muskrat is an adaptable animal that can be expected to increase in abundance in aquatic habitats within the 200 Areas, especially those ditches and ponds supporting rank growthsof aquatic plants. The muskrat population can be eliminated by removing ponds and ditches. Management practices designed to reduce the acreage of ponds and ditch habitat would tend to decrease the suitability of the 200 Areas as muskrat and raccoon habitat. Otherwise, trapping for population control in conjunction with a radiological monitoring program is an alternative management strategy. The raccoon readily climbs chain-link fences. 


\section{MULE DEER}

Mule deer are attracted to the 200 Areas for drinking water and for riparian vegetation as shelter and food. A chain-link fence is a barrier to mule deer and can be expected to be effective in denying access of mule deer to waste management zones.

\section{BLACK-TAILED HARE}

The black-tailed hare depends upon shrub-steppe vegetation. Because it does not burrow, a chain-link fence placed at ground level or a few inches below the normal soil surface would be an effective barrier to hare movements. Hares inside the barrier could still be preyed upon by raptors. 


\section{RADIOECOLOGICAL CONSIDERATIONS}

Some of the mammals associated with the Hanford Reservation, due to their habitat requirements, eating habits, mobility, and status as game animals can serve as pathways for the transportation of radioactive materials from the Reservation to man. Concern should not always be limited to man alone, as there is a certain potential for harm to the animals themselves from exposure to radioactive materials.

\section{MULE DEER}

The mammal with the greatest potential for transferring radioisotopes to man is the mule deer. Resident deer travel to and from the Reservation and during the big-game hunting season they are shot and the meat consumed. Deer are mainly browsers and their diet consists almost entirely of noncultivated plants. Because of this, body burdens of selected radioisotopes are often significantly higher than domestic animals living in the same region. Whicker et al. (1968) reported that the concentration of ${ }^{137} \mathrm{Cs}$ in deer flesh was approximately 10 times higher than that observed in beef and pork over the same time period.

The radioisotope of most concern is ${ }^{137} \mathrm{Cs}$. Approximately $80-90$ percent of total body ${ }^{137} \mathrm{Cs}$ is concentrated in muscle tissue (Hakonson, 1967). Therefore, consumption of venison by man can be a potential source of ${ }^{137} \mathrm{Cs}$. Whicker et aL (1968) noted that the transfer coefficient (percentage of the daily ${ }^{137}$ Cs intake per $\mathrm{kg}$ meat at equilibrium) in deer was approximately 15-30 percent and about 4 percent in beef cattle (Johnson et aL, 1969). The effective half-time of ${ }^{137} \mathrm{Cs}$ in deer is approximately 14 days and about 75 percent of the ingested $C$ s is assimilated from the gastro-intestinal tract. The levels of ${ }^{137} \mathrm{Cs}$ observed in deer on the Hanford Reservation during the last few years, approximately $0.1 \mathrm{pCi} / \mathrm{g}$ wet weight (Bramson et al, 1973), are closely similar to the values as reported by Whicker (1973) for deer collected in the mountains of Colorado. 
Another radioisotope of importance is ${ }^{90} \mathrm{Sr}$ which is concentrated in bone, Strontium-90 is not regarded as a health hazard to man, as the bone is not normally consumed, but if absorbed in large amounts it can be harmful to deer. The effective half-time of ${ }^{90} \mathrm{Sr}$ in deer is about 190 days with an assimilation factor of approximately 10 percent (Schreckhise, 1974). The levels of ${ }^{90} \mathrm{Sr}$ in deer collected on the Hanford Reservation during the past few years are normally at or near background levels (Bramson et al, 1973).

A significant amount of ${ }^{90} \mathrm{Sr}$ is transferred from the deer's diet and from the skeleton to the developing antlers of male deer. This has promoted the idea of using deer antlers as useful indicators of ${ }^{90} \mathrm{Sr}$ levels in forage. However, as Schreckhise (1974) states, this is only feasible if many variables are known. It is doubtful that antlers can be used to quantify contamination levels, but they might be useful for the detection of gross amounts of various bone-seeking pollutants in the deer's environment.

Detectable levels of ${ }^{131}$ I have been observed in the thyroids of deer before the concentration in the deer's forage is high enough to detect (Whicker, 1968). The effective half-time for ${ }^{131} \mathrm{I}$ in deer is approximately 6-7 days and about 25 percent of the ingested iodine is incorporated into the thyroid gland (Gist and Whicker, 1971). In mammals, the thyroid is the largest pool for iodine with smaller amounts found in the circulatory and urinary systems. Therefore, as far as ${ }^{131} \mathrm{I}$ is concerned, the consumption of deer meat does not present a health hazard to man. The varying levels of ${ }^{131} \mathrm{I}$ in deer from the Hanford Reservation are very closely related to the levels in deer observed in Colorado (Hanson etal, 1963). This suggests that the ${ }^{131}$ I observed in Hanford deer is primarily from fallout sources rather than from operations on the Reservation.

Very little is known about the kinetics of plutonium and other transuranic elements in deer. Since, Pu is a bone-seeker, antlers might be useful indicators for the presence of $\mathrm{Pu}$ in the deer's environment. Plutonium239 has been observed in liver and bone of deer collected on the Hanford Reservation (Branison et al, 1973), but the concentrations (less than $1 \mathrm{dpm} / \mathrm{g}$ wet weight) are very similar to the fallout values as reported by Whicker (1973). 


\section{MAMMALS OTHER THAN DEER}

The effective half-times for radiocesium in selected small manmals as reported by Winsor and $0^{\prime} F$ arrell (1970) are presented in Table 3 and range between 5 and 9 days. The biological half-time for mammals not listed in Table 3 can be estimated, according to Reichle et al, (1970), with the following equation:

$$
Y_{C S}=3.458 \times 0.2061
$$

where, $\quad Y_{C s}=$ Biological half-time (days).

$X=$ Live body weight (grams).

The biological half-times for ${ }^{90} \mathrm{Sr}$ and ${ }^{131} \mathrm{I}$ can also be approximated according to the expressions

$$
Y_{S r}=107.4 \times 0.2612
$$

and,

$$
Y_{I}=6.819 \times 0.1341
$$

where, $\quad Y_{S r}=$ Biological half-time for ${ }^{90} \mathrm{Sr}$ (days).

$$
\begin{aligned}
Y_{I_{1}} & =\text { Biological half-time for }{ }^{131} \mathrm{I} \text { (days). } \\
X & =\text { Live body weight (grams). }
\end{aligned}
$$

The assimilation factor for ${ }^{137} \mathrm{Cs}$ in the majority of these smaller mammals ranges from 70 to 100 percent and approximately 10 to 40 percent for ${ }^{9} \mathrm{Sr}$ and $131 \mathrm{I}$.

Very little is known about the assimilation and retention of ingested plutonium for Hanford Reservation wild mammals.

Inhalation of radioactive materials can also be of concern. The retention half-times for lung-absorbed materials for certain compounds of ${ }^{131} \mathrm{I}$ and ${ }^{90} \mathrm{Sr}$ are only a few days, while the half-time for plutonium and uranium can range from 100 to 1500 days (Reichle et al., 1970). 
TABLE 3. Biological half-times of ${ }^{137} \mathrm{Cs}$ in various small mammals native to the Hanford Reservation. Modified from Winsor and 0'Farrell (1970).

\begin{tabular}{lc}
\hline \multicolumn{1}{c}{ Species } & Half-time (days) \\
\hline Sagebrush vole & 4.4 \\
Montane meadow mouse & 4.5 \\
Great Basin pocket mouse & 5.3 \\
Western harvest mouse & 5.4 \\
Northern grasshopper mouse & 5.6 \\
Deer mouse & 6.3 \\
House mouse & 9.4 \\
\hline
\end{tabular}

With the exception of deer, and possibly rabbits and hares, the mammals associated with the Hanford Reservations are not considered as potential pathways for the transfer of radioactive materials from waste management zones to man. However, consideration should be given to the animals themselves in terms of radionuclide body burdens and radiation doses.

\section{RADIATION EFFECTS}

Wild mammals are potentially subjected to external and internal radiation exposures. This is especially true for burrowing animals living in waste management sites and for mammals living in the vicinity of the above ground retrievable surface storage facility proposed for the Hanford Reservation. 
The radio-sensitivity of selected small mammal species living on the Hanford Reservation to acute gamma radiation has been examined by 0'Farrel 1 and Hedlund (1970). The $L_{50 / 30}$ values observed are presented in Table 4. The radio-sensitivity of mammals varies among species, with the pocket mouse having the greatest resistance. The response within a species can also vary, depending on factors such as age reproductive stages and environmental stress conditions. Of the presently available data concerning ionizing radiation, most is related to the biological effects of acute gamma or $X$ irradiation. Essentially no data are available for evaluating long-term effects from chronic irradiation on wild, free-living mammals, nor for neutron irradiation effects.

TABLE 4. Response of Hanford mammals to acute radiation. Modified from 0'Farrell and Hedlund (1970).

\begin{tabular}{ll}
\hline \multicolumn{1}{c}{ Species } & $\mathrm{LD}_{50 / 30}(\mathrm{RAD})$ \\
\hline Northern grasshopper mouse & 534 \\
Western harvest mouse & 701 \\
Northern pocket gopher & 756 \\
House mouse & 795 \\
Great Basin pocket mouse & 856 \\
Deer mouse & 919 \\
\hline
\end{tabular}


TABLE 5. Mammals which warrant special consideration for the management of radioactive wastes.

\begin{tabular}{|c|c|c|c|}
\hline \multirow[t]{3}{*}{$\begin{array}{l}\text { Most } \\
\text { Aquatic }\end{array}$} & I & Muskrat & $\begin{array}{l}\text { Muskrats occur in waste ponds and ditches; } \\
\text { have opportunity to ingest radionuclides } \\
\text { through aquatic plants and direct inges- } \\
\text { tion of pond sediments attached to plants. } \\
\text { Muskrats are prey for the large mammalian } \\
\text { predators and raptors. }\end{array}$ \\
\hline & 11 & Raccoon & $\begin{array}{l}\text { Raccoons occur around waste ponds and have } \\
\text { opportunity to ingest vegetation, fish, } \\
\text { frogs, birds, and other aquatic-oriented } \\
\text { organisms. Raccoons are a nuisance because } \\
\text { of their agility and curiosity. }\end{array}$ \\
\hline & I I I & Mule deer & $\begin{array}{l}\text { Mule deer have access to and often eat vege- } \\
\text { tation associated with pond margins. Mule } \\
\text { deer are mobile enough to leave waste } \\
\text { management zones and be killed by hunters } \\
\text { outside the reservation boundaries. }\end{array}$ \\
\hline \multirow[t]{5}{*}{ abitat } & IV & Coyote & $\begin{array}{l}\text { The coyote is the most important abundant } \\
\text { mammalian predator on the Hanford Reservation } \\
\text { and has access to all waste management zones. }\end{array}$ \\
\hline & V & Badger & $\begin{array}{l}\text { Although not nearly as abundant as the } \\
\text { coyote, the badger has the ability to } \\
\text { dig deep into burial sites and expose } \\
\text { buried material. }\end{array}$ \\
\hline & VI & $\begin{array}{l}\text { Townsend ground } \\
\text { squirrel }\end{array}$ & $\begin{array}{l}\text { Ground squirrels are burrowing animals } \\
\text { with potential to dig into buried wastes. }\end{array}$ \\
\hline & VII & $\begin{array}{l}\text { Black-tailed } \\
\text { hare }\end{array}$ & $\begin{array}{l}\text { The hare is abundant in waste management } \\
\text { zones and provides prey for large predators. } \\
\text { The black-tailed hare is responsible for } \\
\text { biotic dispersion of }{ }^{90} \mathrm{Sr} \text { and }{ }^{137} \mathrm{Cs} \text { in the } \\
\text { B-C Crib area after surface exposure by } \\
\text { burrowing animals. }\end{array}$ \\
\hline & $V \mid I I$ & Pocket mouse & $\begin{array}{l}\text { The pocket mouse is the most abundant mammal } \\
\text { on the Hanford Reservation. It is ubiquitous } \\
\text { throughout the steppe habitat. It is } \\
\text { readily trapped and has a limited home range. } \\
\text { The pocket mouse is prey for all classes } \\
\text { of mammalian predators. }\end{array}$ \\
\hline
\end{tabular}


BASIS FOR FUTURE WORK

Certain mammals, due to their abundance and/or peculiar attributes, justify special considerations in reference to waste management. A summary for the eight species judged to be most important is presented in Table 5. Because the fate and effect of radioactive materials in many of these mammals is unknown, studies are warranted to provide information needed for longterm waste management decisions in relation to mammal populations. A special concern is the role of mammals as vectors in the transport of radioactivity. Except for the Great Basin pocket mouse, reliable data on home range are not available. Although levels of radioactivity may not constitute a proximate hazard to man through the food chain, the transport of waste radionuclides beyond the boundaries of the Hanford Reservation can cause doubt as to public acceptance of the nuclear processing methodology. 
BMML-1877

\section{REFERENCES}

Branison, P. E., J. P. Corley and W. L. Nees. 1973. Environmental Status of the Hanford Reservation for CY-1972. Battell e Northwest Laboratory Report BNWL-B-278. Richland, Washington.

Burt, W. H. and R. P. Grossenheider. 1964. A Field Guide to the Mammals.

Gist, C. S. and F. W. Whicker. 1971. Radioiodine uptake and retention by the mule deer thyroid. J. Wildlife Management 35(3):461-468.

Hakonson, T. E. 1967. Tissue distribution and excretion of ${ }^{137} \mathrm{Cs}$ in the mule deer. M.S. Thesis. Colorado State University, Fort Collins. 121 p. Hanson, W. C., F. W. Whicker and A. H. Dahl. 1963. lodine-131 in the thyroids of North American deer and caribou: Comparison after nuclear tests. Science 140(3568):801-802.

Hedlund, J. D., R. A. Gies and T. P. O'Farre11. 1973. Tagging Hanford deer, Odocoileus hemionus. pp. 7.23-7.24. In: Pacific Northwest Laboratory, Annual Report for 1972. BNWL-1750, Vol. I - Life Sciences, Part 2 - Ecological Sciences. Battelle-Northwest, Richland, Washington. Ingles, L. G. 1965. Mammals of the Pacific States. Stanford University Press, Stanford, California.

International Commission on Radiological Protection. 1959. Report of Committee II on Permissible Dose for Internal Radiation. ICRP publication 2. Pergamon Press, New York. 233 p.

Johnson, J. E., T. R. Tyler and G. M. Ward. 1969. Transfer of fallout cesium-137 from feed to meat of cattle. J. Animal Science 29(5):695-699. 
Kritzman, E. B. 1970. Niche Fit and Overlap of Peromyscus rnaniculatus and Perognathus parvus in Eastern Washington. M.S. Thesis, University of Washington, Seattle. $86 \mathrm{p}$.

Kritzman, E. B. 1974. Ecological relationships of Peromyscus maniculatus and Perognathus parvus in Eastern Washington. J. Mammal. 55:172-188. O'Farrell, T. P. 1972. Ecological distribution of sagebrush voles, Lagurus curtatus, in south-central Washington. J. Manmal. 53:632-636. O'Farrell, T. P., J. D. Hedlund, R. J. Olson and R. 0. Gilbert. 1972. Effects of ionizing radiation on survival, longevity, and reproduction in free-ranging pocket mice, Perognathus parvus. Radiat. Res. 49:611-623. O'Farrell, T. P. and J. D. Hedlund. 1970. Effects of acute radiation in native rodents, pp. 2.13 Ln: Pacific Northwest Laboratory, Annual Report for 1969. BNWL-1306, Vol. 1 - Life Sciences, Part 2 - Ecological Sciences. Battelle-Northwest, Richland, Washington.

O'Farrell, T. P. and J. D. Hedlund. 1972. White-tailed deer, Odocoileus virginianus, in south-central Washington. J. Manmal. 53:907-909. O'Farrell, T. P., R. J. Olson, R. 0. Gilbert and J. D. Hedlund. 1974. A population of Great Basin pocket mice, Rerngnathws parvus, in the shrubsteppe of south-central Washington. (In press) Ecological Monographs.

Reichle, D. E., P. B. Dunaway and D. J. Nelson. 1970. Turnover and concentration of radionuclides in food chains. Nuclear Safety 11(1):43-55.

Schreckhise, R. G. 1974. Strontium Kinetics in Mule Deer. Ph.D. Dissertation, Colorado State University, Fort Collins. $76 \mathrm{p}$.

Schreiber, R. K. 1973. Bioenergetics of Rodents in the Northern Great Basin Desert. Ph.D. Dissertation, University of Idaho, Moscow. 133 p. 
U.S. Department of Interior. 1973. Threatened Wildlife of the United States. Pub. by Bureau of Sport Fisheries and Wild7ife, Washington, DC, Pub. 114. Whicker, F. W. 1973. Fallout ${ }^{137}$ Cs and ${ }^{131} \mathrm{I}$ in mule deer and vegetation, winter 1972-73. pp. 34-37 In: Eleventh Annual Progress Report to the U.S. Atomic Energy Commission. Contract AT(11-1)-1156 (Department of Radiology and Radiation Biology, Colorado State University, Fort Collins).

Whicker, F. W., G. C. Farris and A. H. Dahl. 1968. Wild deer as a source of radionuclide intake by humans and as indicators of fallout hazards. pp.1105-1110, In Proceedings of the First International Congress of Radiation Protection. Pergamon Press Oxford.

Winsor, T. F. and T. P. O'Farre11. 1970. Retention of ${ }^{137} \mathrm{Cs}$ in eight species of native rodents, pp. 2.18-2.19 In. Pacific Northwest Laboratory, Annual Report 1969. BNWL-1306, Vol. 1 - Life Sciences, Part 2 Ecological Sciences. Battelle-Northwest, Richland, Washington. 
BNWL- 1877

Special Distributionin

DISTRIBUTION LIST

Category UC-70

AEC Chicago Patent Group

5

Division of Biomedical and Environmental

Research, USAEC

I - L. Brisbin

J. L. Liverman

C. L. Osterberg

J. Swinebroad

R. L. Watters

Division of Waste Management and Transportation, USAEC

G. H. Daly

F. K. Pittman

R. W. Ramsey

R. A. Wolfe

Division of Production and Materials Management, USAEC

F. P. Baranowski

J. W. Polloch

G. B. Pleat

W. R. Voight Jr.

Argonne National Laboratory

9700 South Carr Avenue

Argonne, Illinois 60439

Librarian

Brookhaven National Laboratory

Research Library, Reference Section

Upton, L. I _ , New York 11973

E. I - duPont De Nemours and Co.

Aiken

Savannah River Laboratory

Technical Information Service

Room 773-A

Aiken, South Carolina 29801

Lawrence Radiation Laboratory

Lawrence Livermore Laboratory

Technical Information Dept., L-3

P. 0. Box 808

Livermore, California 94550 
Los Alamos Scientific Laboratory

P. 0. Box 1663

Los Alamos, New Mexico 87544

W. C. Hanson

Tom Hakonson

1

Oak Ridge National Laboratory

Oak Ridge Operations Office

Oak Ridge, Tennessee 37830

\section{S. I Auerbach}

1

USAEC Nevada Operations Office

P.O. Box 14100

Las Vegas, Nevada 89114

P. Dunaway

$\underline{\text { Individuals in the United States }}$

Dr. Leo K. Bustad

Dean, College of Veterinary Medicine

Washington State University

Pullman, Washington 99163

Mr. Jared J. Davis

Assistant Director for Site and Health Standards

Directorate of Regulatory Standards

USAEC

Washington, DC 20545

Dr. 0. Doyle Markham

Environmental Sciences Branch

Health Services Laboratory

USAEC

P. 0. Box 2108

Idaho Falls, Idaho 83401

Dr. Vincent B. Schultz

Department of Zoology

Washington State University

Pullman, Washington 99163

Dr. F. Ward Whicker

Radiology and Radiation Biology Department

Colorado State University

Fort Collins, Colorado 80521 
Dr. David Willis

Chairman, Department General Sciences

Oregon State University

Corvallis, Oregon

Dr. Donald Johnson

Zoology Dept.

University of Idaho

Moscow, Idaho

Dr. Terrol Winsor

Radiology and Radiation Biology Department

Colorado State University

Fort Col 1ins, Colorado 80521

Dr. Mike Smith, Director

Savannah River Ecology Laboratory

Drawer E

Aiken, South Carolina 29801

Ons it e

1

Patent Attorney

4

AEC/RL

B. J. Melton/Paul Dunigan, Jr.

0. J. Elgert/R. B. Goranson

J. L. Rhoades/D. Smith

F. R. Standerfer

50

Battelle Northwest

E. L. Alpen

W. J. Bair

J. P. Corley

L. L. Eberhardt

R. F. Foster

J. J. Fuquay

W. H. Rickard (5)

J. K. Soldat

W. L. Templeton (5)

C. M. Unruh

B. E. Vaughan (5)

E. L. Klepper (5)

J. D. Hedlund (5)

R. E. Fitzner

R. G. Schreckhise (5)

Biology Library (3)

Technical Information (5)

Technical Publications (3) 
M. D. Alford

H. Babad

G. E. Backman

D. G. Braden

D. J. Brown

L. E. Bruns (5)

G. Burton, Jr.

M. H. Campbell

R. E. Felt

L. W. Finch

D. R. Gustavson

G. L. Hanson

W. M. Harty (5)

H. H. Hopkins, Jr.

R. E. Isaacson (10)

C. W. Malody

H. L. Maxfield

T. R. McKenzie

B. J. McMurray

D. C. Nelson

G. C. Oberg

K. R. Price

M. F. Rice

G. H. Sahler

C. M. Salina

H. P. Shaw

A. E. Smith

R. M. Smithers

G. T. Stocking

M. J. Szulinski

V. A. Uresk (5)

J. H. Warren

D. D. Wodrich 